\title{
Detection and Characterization of an Elm Yellows (16SrV) Group Phytoplasma Infecting Virginia Creeper Plants in Southern Florida
}

\author{
N. A. Harrison, University of Florida, Fort Lauderdale Research and Education Center, Ft. Lauderdale 33314; \\ H. M. Griffiths, Department of Plant Pathology, Cornell University, Ithaca, NY 14853-4203; and M. L. Carpio \\ and P. A. Richardson, University of Florida, Fort Lauderdale Research and Education Center
}

\begin{abstract}
Harrison, N. A., Griffiths, H. M., Carpio, M. L., and Richardson, P. A. 2001. Detection and characterization of an elm yellows (16SrV) group phytoplasma infecting Virginia creeper plants in southern Florida. Plant Dis. 85:1055-1062.

The polymerase chain reaction (PCR) employing phytoplasma-specific ribosomal RNA primer pair P1/P7 consistently amplified a product of expected size $(1.8 \mathrm{~kb})$ from 29 of 36 symptomless Virginia creeper (Parthenocissus quinquefolia) plants growing in southern Florida. Restriction fragment length polymorphism analysis of P1/P7-primed PCR products indicated that most phytoplasmas detected in Virginia creeper were similar to phytoplasmas composing the elm yellows $(16 \mathrm{SrV})$ group. This relationship was verified by reamplification of P1/P7 products using an elm yellows (EY) group-specific rRNA primer pair fB1/rULWS1. rDNA products $(1,571 \mathrm{bp})$ were generated by group-specific PCR from 28 phytoplasma-positive plants and 1 negatively testing plant identified by earlier P1/P7-primed PCR. Analysis of 16S rDNA sequences determined the Virginia creeper (VC) phytoplasma to be phylogenetically closest to the European alder yellows (ALY) agent, an established $16 \mathrm{SrV}-\mathrm{C}$ subgroup strain. However, presence or absence of restriction sites for endonucleases $A l u \mathrm{I}, B f a \mathrm{I}, M s p \mathrm{I}, R s a \mathrm{I}$, and $T a q \mathrm{I}$ in the 16S rRNA and 16-23S rRNA intergenic spacer region of the VC phytoplasma collectively differentiated this strain from ALY and other $16 \mathrm{SrV}$ group phytoplasmas. Failure to detect the VC phytoplasma by PCR employing nonribosomal primer pair FD9f/FD9r suggests that this newly characterized agent varies from known European grapevine yellows (flavescence dorée) phytoplasmas previously classified as $16 \mathrm{SrV}$ subgroup $\mathrm{C}$ or D strains.
\end{abstract}

Additional keywords: phytoplasma identification, Vitaceae

Virginia creeper (Parthenocissus quinquefolia (L.) Planch.), also known by other names such as woodbine, American ivy, and five-fingered ivy, is a hardy, fast-growing, deciduous vine native to eastern North America. Wide-ranging in its distribution, this member of the grape family (Vitaceae) commonly can be found growing in woodland and hedgerows from Nova Scotia, Canada to southern Florida and as far west as Texas and Oklahoma, where it is often the most prevalent plant species in both bottomland and oak-hickory forests (28).

Virginia creeper (VC) is a close relative of grapevine (Vitis vinifera L.), a wellknown host of debilitating yellows-type diseases which reportedly occur in many regions of the world where grape is culti-

Corresponding author: N. A. Harrison

E-mail: naha@ufl.edu

GenBank accession numbers of DNA sequences: AF305198, AF305240.

Florida Agricultural Experiment Station Journal Series No. R-07898.

Accepted for publication 12 June 2001.

Publication no. D-2001-0723-03R

(C) 2001 The American Phytopathological Society vated $(1,4,25,29,31)$. Etiological studies have implicated the involvement of several distinct phytoplasma strains which differ in their global distribution and incidence in vineyards. Using polymerase chain reaction (PCR) and restriction fragment length polymorphism (RFLP) analysis, strains involved have been shown to belong to groups 16SrI (aster yellows and related strains), 16SrIII (X-disease and related strains), $16 \mathrm{SrV}$ (elm yellows and related strains), and 16SrXII (stolbur and related strains) according to the classification system of Lee et al. (20). Distribution of group $16 \mathrm{SrV}$ phytoplasmas associated with grapevine flavescence dorée (FD) is apparently limited to viticultural areas of western Europe $(2,25,31)$, although strains serologically related to FD were detected in grapevine and the FD vector leafhopper Scaphoideus titanus Ball in New York state (22). Elsewhere in the eastern United States, where grapevine yellows diseases are known to occur, affected $V$. vinifera plants were shown to contain phytoplasmas belonging to groups $16 \mathrm{SrI}$ or $16 \mathrm{SrIII}$ (4). Symptomless wild grapevine (V. riparia Michx.) adjacent to vineyards also harbored phytoplasmas $(1,4)$ capable of infecting cultivated grapevine (22).

Symptoms suggestive of yellows disease were observed on several mature $\mathrm{VC}$ vines growing along fence lines at the University of Florida's Fort Lauderdale Research and Education Center (FLREC) during May 1998. The vines possessed small, crinkled, mildy chlorotic leaves and shoot proliferation which prompted us to examine them for evidence of phytoplasma infection. Although it was learned later that "symptoms" on the plants were a result of herbicide treatment rather than disease, phytoplasmas were detected by PCR in both "symptomatic" plants and "asymptomatic" plants alike during this preliminary investigation (N. A. Harrison, unpublished data). The present study was undertaken during June and July 2000 to determine the identity and incidence of phytoplasmas in this newly recognized vitaceous host species. We report the presence of elm yellows group $(16 \mathrm{SrV})$ phytoplasmas in the majority of symptomless VC plants examined at random from among the resident population on the grounds of the FLREC. Detected phytoplasmas were distinct from known grapevine-infecting $16 \mathrm{SrV}$ group phytoplasmas, and phylogenetically closest to European alder yellows (ALY) agent (26), previously designated as a $16 \mathrm{SrV}-\mathrm{C}$ subgroup member (20).

\section{MATERIALS AND METHODS}

Plant samples and phytoplasma reference strains. Samples consisting of young leaves from the tips of vines were collected during May 1998 and in June and July 2000 from a total of 36 apparently symptomless VC plants on the grounds of the FLREC. Phytoplasmas used for comparative purposes included the following strains: elm yellows (EY1) (7), eastern aster yellows (EAY), western $\mathrm{X}$ (WX), Mexican periwinkle virescence (MPV) (11), and pigeonpea witches'-broom (PPWB) (14), each maintained separately in periwinkle (Catharanthus roseus (L.) G. Don). A Florida strain of the maize bushy stunt (MBSF) phytoplasma was maintained in sweet corn (Zea mays L. var. saccharata (Sturtev.) L. H. Bailey) by periodic transmissions using vector Dalbulus maidis leafhoppers (13). DNA of the palm lethal yellowing (LY) phytoplasma was obtained from immature leaf tissues of a coconut palm (Cocos nucifera L.) displaying typical LY symptoms (12). The beet leafhopper-transmitted virescence agent (BLTVA), Brachiara white leaf (BraWL), flavescence dorée (FD70), Gliricidia (G. sepium) little 
leaf (GLL), jujube (Ziziphus jujube) witches'-broom (JWB), sweet potato (Ipomoea batatas) little leaf (SPLL), and Rubus stunt (RuS) strains were provided to us by other researchers either as DNA samples or in plant tissues. Seedling periwinkle was used as a healthy standard because known healthy VC plants were unavailable during this study.

DNA extraction. Total nucleic acid was extracted from $0.5 \mathrm{~g}$ of dried or $3 \mathrm{~g}$ of fresh plant foliage by the method of Doyle and Doyle (6), except for VC tissues, which were extracted using a modified phytoplasma enrichment method (17) as follows. Samples $(1.5 \mathrm{~g})$ of freshly harvested leaf petioles were diced with a razor blade and ground thoroughly in a mortar and pestle containing $12 \mathrm{ml}$ of warm $\left(25^{\circ} \mathrm{C}\right)$ grinding buffer and sea-washed sand to facilitate the grinding process. The resulting viscous slurry was transferred to a sterile $30-\mathrm{ml}$ Corex centrifuge tube and diluted with an additional $15 \mathrm{ml}$ of grinding buffer before centrifugation at $3,000 \times g$ for $10 \mathrm{~min}$ at $25^{\circ} \mathrm{C}$. The partially clarified supernatent was decanted to another sterile 30-ml Corex tube and centrifuged again at $20,000 \times g$ for $30 \mathrm{~min}$. After discarding the supernatent, nucleic acids were extracted from the residual pellet as previously stated (6). Ethanolprecipitated nucleic acids derived from each pellet were resuspended in 50 to $100 \mu \mathrm{l}$ of TE (10 mM Tris, 1 mM EDTA, pH 8) buffer containing RNAse and incubated at $37^{\circ} \mathrm{C}$ for $1 \mathrm{~h}$. Resulting DNA extracts were quantified by fluorometry (TK-100 minfluorometer; Hoefer Scientific, San Francisco, CA) and stored at $4^{\circ} \mathrm{C}$ before use.
PCR analysis. DNA samples used as templates for PCR were first diluted to 25 $\mathrm{ng} / \mu \mathrm{l}$ with sterile deionized water. Amplifications were performed in 50- $\mu$ l final reaction volumes, each containing $50 \mathrm{ng}$ of DNA template, $50 \mathrm{ng}$ of each primer, 125 $\mu \mathrm{M}$ of each dNTP, $1 \mathrm{U}$ of Taq DNA polymerase (Promega Corp., Madison, WI), and standard PCR buffer containing 1.5 $\mathrm{mM} \mathrm{MgCl}_{2}$ (15). PCR was performed for 35 cycles in a PTC/100 programmable thermal controller with hot bonnet (MJ Research Inc., Watertown, MA) employing phytoplasma-specific rRNA primer pair P1 and P7, which amplifies almost the entire $16 \mathrm{~S}$ rRNA gene, the 16-23S rRNA spacer region, and the 5 -end of the $23 \mathrm{~S}$ rRNA gene (38). The following thermal cycling parameters were used: denaturation for 30 s (90 s for first cycle) at $94^{\circ} \mathrm{C}$, annealing for $50 \mathrm{~s}$ at $55^{\circ} \mathrm{C}$, and extension for $80 \mathrm{~s}$ at $72^{\circ} \mathrm{C}$. Reactions were terminated after the final cycle with a $10-$ min extension step at $72^{\circ} \mathrm{C}$, then cooled to $4^{\circ} \mathrm{C}$. VC DNAs were subsequently reassessed by PCR employing nonribosomal primers FD9f/FD9r using previously reported thermal cycling conditions (2).

Products resulting from P1/P7 amplifications were diluted $1: 40$ or $1: 100$ with sterile deionized water and $3 \mu \mathrm{l}$ of each dilution, then used as template during 30 cycles of PCR with nested elm yellows group-specific rRNA primer pair fB1/rULWS1, as previously described (38). Aliquots (5 or $10 \mu \mathrm{l}$ ) of each PCR reaction were evaluated by electrophoresis through 1\% agarose (low EEO; Fisher Scientific, Pittsburgh, PA) gels using $1 \times$
TAE (40 mM Tris-acetate, $1 \mathrm{mM}$ EDTA) as running buffer. Products in gels were stained with ethidium bromide (EtBr), visualized by UV transillumination, and photographed.

DAPI staining test. Serial transverse sections were cut with a razor blade from petioles of VC plants known to contain phytoplasmas following their assessment by PCR. Sections were stained with an aqueous solution of the DNA-binding fluorochrome DAPI (4'-6-diamidino-2phenylindole), mounted in clear corn syrup on a microscope slide, and examined for phytoplasma infection by epifluorescence microscopy as described by Sinclair et al. (37).

RFLP analysis of PCR products. Aliquots $(5 \mu \mathrm{l})$ of each P1/P7-primed PCR product were digested separately with $10 \mathrm{U}$ of restriction endonucleases $B f a \mathrm{I}$ (New England BioLabs, Beverly, MA), AluI, DdeI, DraI, EcoRI, HaeIII, HhaI, MspI, $R s a \mathrm{I}$, and Sau3AI (Promega Corp.) at $37^{\circ} \mathrm{C}$, with $B s t \mathrm{UI}$ (New England BioLabs) at $60^{\circ} \mathrm{C}$, or with $T a q \mathrm{I}$ and $\operatorname{Tr} u 9 \mathrm{I}$ (Promega Corp.) at $65^{\circ} \mathrm{C}$ for a minimum of $16 \mathrm{~h}$. Digests were separated by electrophoresis through $8 \%$ nondenaturing polyacrylamide gels using $1 \times$ TBE $(90 \mathrm{mM}$ Tris-borate, 2 $\mathrm{mM}$ EDTA) as running buffer. Products in gels were resolved and recorded as previously described.

Sequencing of PCR products. $\mathrm{P} 1 / \mathrm{P} 7$ primed rDNA products from $\mathrm{VC}$ sample VC2 and jujube witches'-broom (JWB) were each purified on spin columns (QIAquick PCR Purification Kit; Qiagen, Valencia, CA) and eluted with sterile ul-

Table 1. Description of phytoplasma $16 \mathrm{~S}$ rDNA sequences used in this study

\begin{tabular}{|c|c|c|c|}
\hline Phytoplasma or associated disease & $\begin{array}{l}\text { 16S rRNA group- } \\
\text { subgroup affiliation }\end{array}$ & GenBank accession no. & Reference \\
\hline Michigan aster yellows (MiAY) & 16SrI-B & M30790 & 21 \\
\hline Japanese hydrangea phyllody (JHP) (“Candidatus Phytoplasma japonicum”) & 16SrI-D & AB010425 & 32 \\
\hline Peanut witches'-broom (PnWB) & 16SrII-A & L33765 & 10 \\
\hline Witches'-broom disease of lime (WBDL) (“Candidatus Phytoplasma aurantifolia”) & 16SrII-B & X76433 & 42 \\
\hline Faba bean phyllody (FBP) & 16SrII-C & X83432 & 34 \\
\hline Western X (WX) & 16SrIII-A & L04682 & 34 \\
\hline Clover yellow edge (CYE) & 16SrIII-B & L33766 & 10 \\
\hline Palm lethal yellowing (LY) & 16SrIV-A & U18747 & 39 \\
\hline Elm yellows (EY1) & $16 \mathrm{SrV}-\mathrm{A}$ & AF189214 & 7 \\
\hline Elm yellows (EY-WV) & $16 \mathrm{SrV}-\mathrm{A}$ & AF122911 & 7 \\
\hline Ulmus witches'-broom (ULW) & $16 \mathrm{SrV}-\mathrm{A}$ & X68376 & 34 \\
\hline Jujube witches'-broom (JWB) & 16SrV-B & AF305240 & This article \\
\hline Alder yellows (ALY) & $16 \mathrm{SrV}-\mathrm{C}$ & Y16387 & 34 \\
\hline Hemp dogbane yellows (HD1) & $16 \mathrm{SrV}-\mathrm{C}$ & AF122912 & 7 \\
\hline Virginia creeper $(\mathrm{VC})$ & $16 \mathrm{SrV}-\mathrm{C}$ & AF305198 & This article \\
\hline Flavescence dorée (FD) & 16SrV-D & $\mathrm{X} 76560$ & 34 \\
\hline Rubus stunt (RuS) & 16SrV-E & Y16395 & 34 \\
\hline Clover proliferation $(\mathrm{CP})$ & 16SrVI-A & L33761 & 10 \\
\hline Ash yellows (AshY1) (“Candidatus Phytoplasma fraxini”) & 16SrVII-A & AF189215 & 9 \\
\hline Loofah witches'-broom (LfWB) & 16SrVIII-A & L33764 & 10 \\
\hline Pigeon pea witches'-broom (PPWB) & 16SrIX-A & U18763 & 39 \\
\hline Apple proliferation (AT) & 16SrX-A & X68375 & 34 \\
\hline Buckthorn witches'-broom (BWB) & $16 \mathrm{SrX}-\mathrm{E}$ & X76431 & 34 \\
\hline Rice yellow dwarf (RYD) & 16SrXI-A & D12581 & 27 \\
\hline Stolbur (STOL) & 16SrXII-A & X76427 & 34 \\
\hline Australian grapevine yellows (AUGY) ("Candidatus Phytoplasma australiense") & 16SrXII-B & X95706 & 29 \\
\hline Bermuda grass white leaf (BGWL) & 16SrXIV & Y16388 & 34 \\
\hline Hibiscus witches'-broom (HibWB) (“Candidatus Phytoplasma brasiliense”) & $16 \mathrm{SrXV}$ & AF147708 & See addendum \\
\hline Acholeplasma laidlawii & Not applicable & M23932 & 41 \\
\hline
\end{tabular}


trapure water. The VC phytoplasma rDNA product was then sequenced directly using automated equipment at Cornell University's Biotechnology Center. The JWB rDNA product was cloned in vector pGEM$\mathrm{T}$ (Promega Corp.) and Escherichia coli DH5 $\alpha$ cells (BRL Life Technologies, Rockville, MD) according to the manufacturer's instructions prior to automated sequencing at the University of Florida's Core DNA sequencing laboratory. The following primers were used to obtain extended sequence reads from the cloned JWB rDNA product: P1, P7, (38), 503f (5'-CAGCAGCCGCGG TAATACATA-3'), 503r $\quad\left(5^{\prime}\right.$-TATGTATT ACCGCGGCTGCTG-3'), 1033 f (5'-TTG TCGTCAGCTCGTGTC-3'), and 1033r (5'-GACACGAGCTGACGACAA -3').

Analysis of phytoplasma rDNA products. Sequences derived from VC and JWB phytoplasma P1/P7-primed rDNA products were assembled and putative endonuclease recognition sites in each sequence were mapped using Vector NTI 5 Suite software (Informax Inc., Bethesda, MD). Maps were examined for concordance with restriction sites previously identified by enzymatic digestion and compared with rDNA sequences of related phytoplasmas selected from the GenBank database. Pairwise comparisons of phytoplasma 16S rDNA sequences were obtained by Gap analysis (Wisconsin package version 10.1; Genetics Computer Group [GCG], Madison, WI). For phylogenetic analysis, 16S rDNA sequences of the VC and JWB phytoplasmas, 26 other phytoplasma strains representing 14 primary phytoplasma groups according to the classification scheme of Lee et al. (20), and Acholeplasma laidlawii (Table 1) were edited and aligned using SeqEd and PileUp programs (Wisconsin package version 10.1). Pairwise evolutionary distances between aligned sequences were created by Distances (SeqWeb version 1.2; GCG) incorporating the Kimura-2 parameter distance correction method. A phylogenetic tree was reconstructed by NeighborJoining from the distance matrix using GrowTree (SeqWeb) and visualized by TreeView (30).

\section{RESULTS}

Phytoplasma detection in VC. Template DNA from VC samples suitable for PCR was readily obtained with minor modifications to the phytoplasma enrichment method. Phytoplasmas were detected by P1/P7-primed PCR in 29 of $36(80.5 \%)$ symptomless VC plants sampled on the grounds of the FLREC during May 1998 and June and July 2000. Positive detections were identified as weak or moderate amplification of an rDNA product of about 1.8 $\mathrm{kb}$. Presence of at least one additional smaller size band in gel profiles indicated that nontarget products were also amplified from some plant samples. Amplification products typical of those obtained by P1/P7-primed PCR are illustrated in Figure $1 \mathrm{~A}$.

Phytoplasma infection of VC determined by PCR was also investigated by the DAPI staining test. Fluorescence due to DAPI staining was clearly observed in transverse sections from only two of eight plants examined by this means. In these plants, staining was confined to a few scattered phloem sieve tubes of sections, suggesting that phytoplasmas were present in these tissues in low titer. Unequivocal detection of phytoplasmas in six remaining test plants was prevented by a constitutive
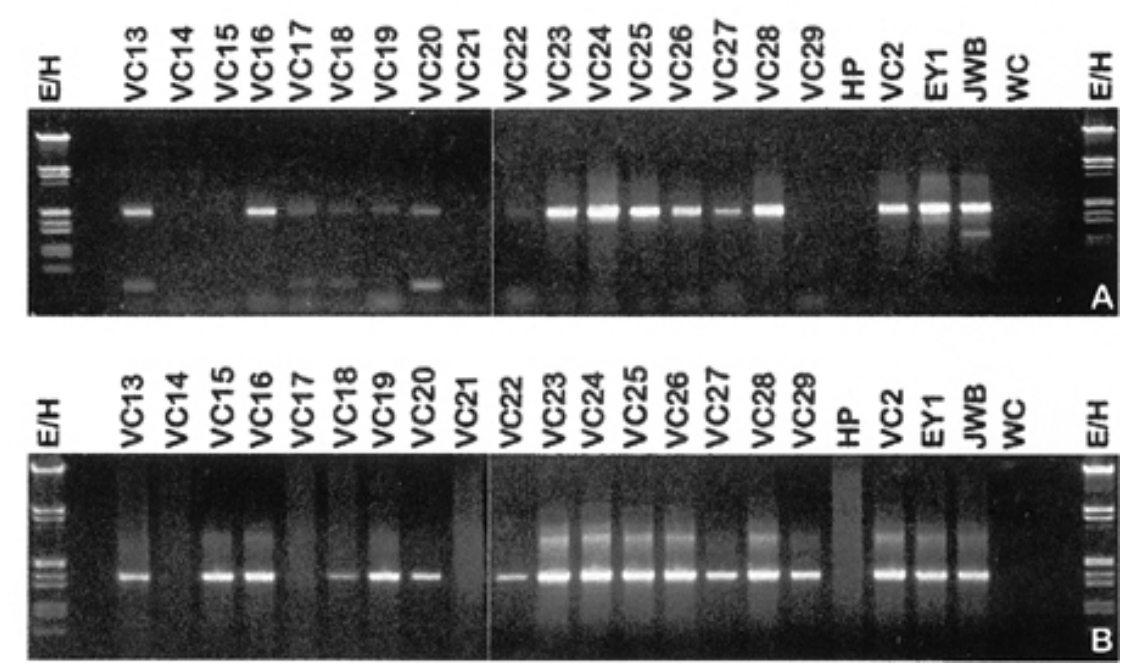

Fig. 1. Agarose gel electrophoresis of rDNA products amplified from DNAs of symptomless Virginia creeper (Parthenocissus quinquefolia) plants by polymerase chain reaction (PCR) assays. Products generated by $\mathbf{A}$, PCR incorporating phytoplasma-specific rRNA primer pair P1/P7 and $\mathbf{B}$, reamplification of P1/P7 products with nested elm yellows (EY) phytoplasma group-specific rRNA primer pair fB1/rULWS1. Template DNA samples were derived from: VC, Virginia creeper plants; HP, healthy periwinkle; EY1, elm yellows phytoplasma; JWB, jujube witches'-broom phytoplasma; and WC, water control. E/H, HindIII/EcoRI digested lambda DNA, fragment sizes (kb) in descending order: $21.12,5.11,4.97,4.3,3.53,2.03,1.9,1.58,1.37,0.95,0.83,0.56,0.12$.

reddish pigment, presumably anthocyanins, which leached from petiole sections and masked sieve tube staining (data not shown).

Phytoplasma characterization. When RsaI digests of P1/P7 amplification products derived from phytoplasma-infected VC sample VC2 and 12 additional strains representative of nine distinct phylogenetic groups of phytoplasmas were compared, resulting rDNA fragment profiles indicated the phytoplasma associated with this plant was most similar to elm yellows phytoplasma EY1, an established $16 \mathrm{SrV}$ group member (Fig. 2). Reamplification of a 1,571-bp product from primary $\mathrm{P} 1 / \mathrm{P} 7$ products by $\mathrm{PCR}$ incorporating nested rRNA primer pair fB1/rULWS1 demonstrated that 28 additional VC plants also contained EY group phytoplasmas. These included 27 known phytoplasma-positive plants and 1 negatively testing plant based on the outcome of initial P1/P7-primed PCR (Fig. 1B). Only P1/P7-positive sample $\mathrm{VC} 17$ failed to yield an rDNA product as a result of this nested PCR assay, indicating that this particular plant harbored a phytoplasma other than an EY group strain. The identity of the latter phytoplasma remains to be determined.

Similarity between VC-inhabiting phytoplasmas and other known group $16 \mathrm{SrV}$ strains was substantiated by additional separate digestions of $\mathrm{P} 1 / \mathrm{P} 7$ products with

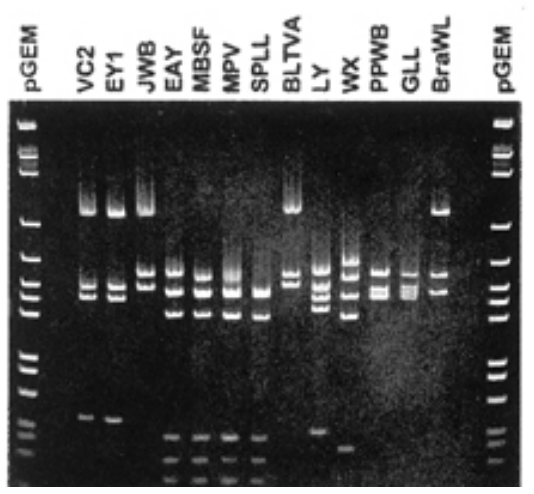

Fig. 2. Comparison of restriction fragment profiles resulting from $R s a \mathrm{I}$ endonuclease digestion of rDNA products $(1.8 \mathrm{~kb})$ amplified from various phytoplasma-infected plants by a polymerase chain reaction (PCR) assay incorporating rRNA primer pair P1/P7. Fragment profiles were resolved by ethidium bromide staining after electrophoresis through $8 \%$ polyacrylamide gels. PCR products were derived from the following phytoplasma DNA templates: VC2, symptomless Virginia creeper; EY1, elm yellows; EAY, eastern aster yellows; MPV, Mexican periwinkle virescence; BLTVA, beet leafhopper-transmitted virescence agent; WX, western X; PPWB, pigeon pea witches'broom; JWB, jujube witches'-broom; MBSF, maize bushy stunt; SPLL, sweet potato little leaf; coconut lethal yellowing; GLL, Gliricidia little leaf; and BraWL, Brachiara white leaf. pGEM: molecular size (bp) markers in descending order: $2645,1605,1198,676,517$, 460, 396, 350, 222, 179, 126, 75, 65, 51, 36. 
AluI, BfaI, MspI, RsaI, or TaqI, because these endonucleases collectively produced the most informative rDNA RFLP patterns during an earlier analysis of phytoplasma strain VC2 employing a total of 13 endonucleases (data not shown). Digests with $A l u \mathrm{I}$ revealed no clear differences between VC phytoplasmas and strains EY1, JWB, FD70, or RuS (Fig. 3A), whereas MspI and $R s a$ I digests each distinguished the JWB phytoplasma from the other strains (Fig. $3 \mathrm{~B}$ and $\mathrm{C}$ ). BfaI digests produced seemingly identical fragment profiles for $\mathrm{VC}$ phytoplasmas, FD70, and RuS which were distinct from profiles of strains EY1 and JWB (Fig. 3D). TaqI profiles distinguished VC phytoplasmas from all other strains except JWB (Fig. 3E), whereas MspI, RsaI, and TaqI profiles collectively differentiated VC phytoplasmas from the other four group- $16 \mathrm{SrV}$ strains.

For infected VC plants that yielded insufficient P1/P7 product to permit RFLP analysis, the identity and uniformity of the associated phytoplasmas was determined by BfaI, RsaI, or TaqI (Fig. 4) digestion of nested products obtained by fB1/rULWS1primed PCR. Fragment profiles revealed by these analyses were uniform and conformed to those obtained for strain $\mathrm{VC} 2$, indicating that each of these additional plants also contained very similar or possibly the same phytoplasma strain.

Thirty-five cycles of PCR primed by nonribosomal primer pair FD9f/FD9r amplified a DNA product of anticipated size $(1.3 \mathrm{~kb})$ from EY1, FD70, HD1, RuS, and JWB phytoplasma DNAs. By comparison, this assay consistently failed to generate a discernible product from any VC plants. Lack of amplification indicated that phytoplasmas infecting the latter host species varied from the other established $16 \mathrm{SrV}$ group strains in another as yet uncharacterized region of their genomes (data not shown).

Nucleotide sequence, sequence similarities, and putative restriction sites in phytoplasma rRNA operon sequences. The rDNA sequences of VC and JWB phytoplasma strains determined in this study have been deposited in the GenBank database under accession numbers AF305198 and AF305240, respectively. Pairwise similarities between 16S rDNA sequences of these strains and those of other known $16 \mathrm{SrV}$ phytoplasmas ranged from 98.99 to $99.93 \%$, respectively. This range of values is consistent with the inclusion of both VC and JWB phytoplasmas in the EY phytoplasma group, as was deduced from earlier rDNA RFLP comparisons (this article). Based on putative restriction site analysis, both phytoplasmas could be differentiated from each other and from five other EY group strains by presence or absence of key $A l u \mathrm{I}, B f a \mathrm{I}, M s p \mathrm{I}, R s a \mathrm{I}$, and $T a q I$ endonuclease recognition sites in their respective $16 \mathrm{~S}$ and $16-23 \mathrm{~S}$ rDNA sequences (Fig. 5). A combination of single sites for $B f a \mathrm{I}$ and $R s a \mathrm{I}$ located at positions 1061 and 1243, respectively, in the $16 \mathrm{~S}$ rDNA, along with an AluI site at position 1607 and two sites for TaqI at positions 1653 and 1700 in the $16-23 \mathrm{~S}$ spacer region,
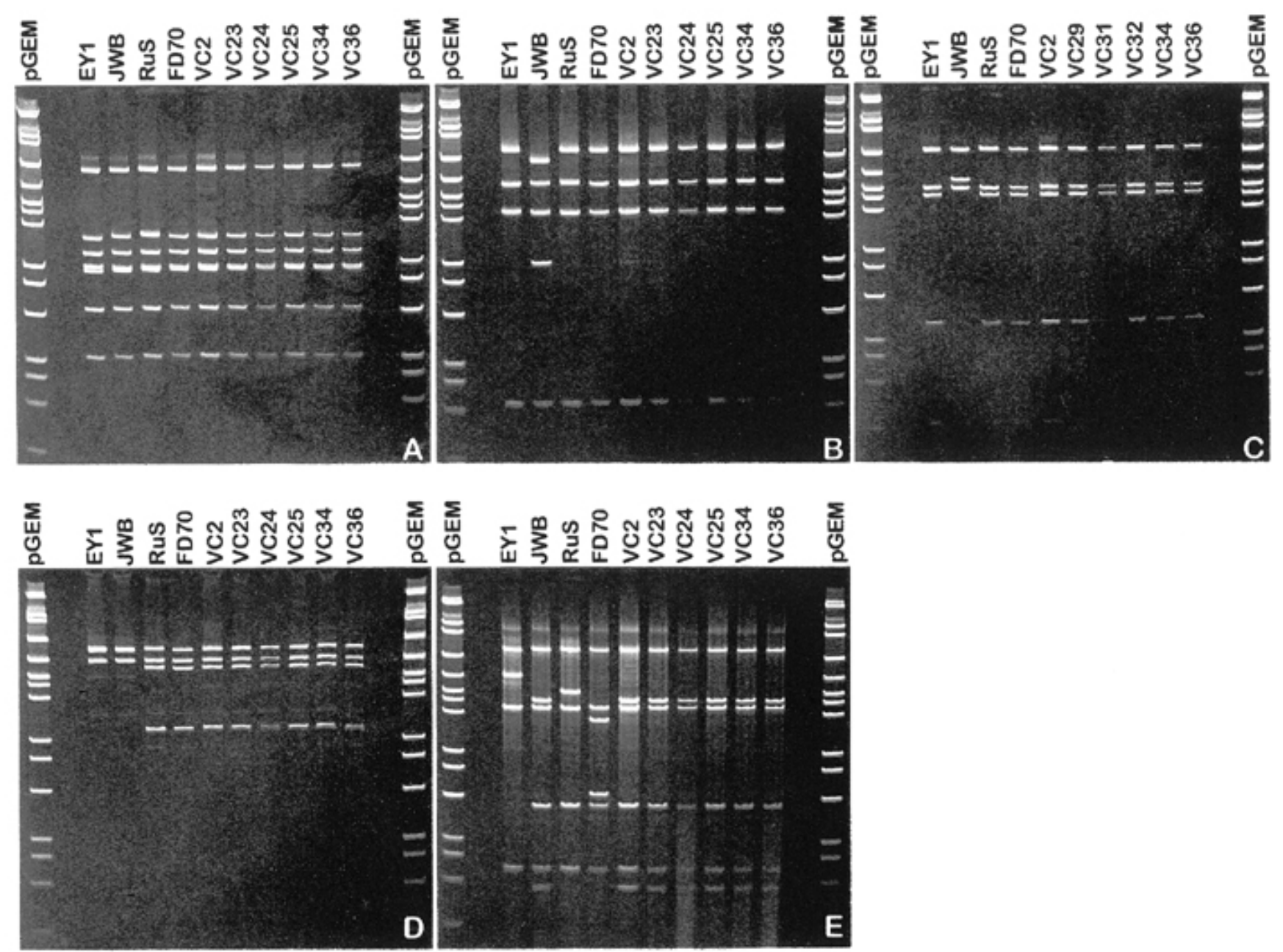

Fig. 3. Restriction fragment length polymorphism (RFLP) profiles of rDNA (1.8 kb), amplified by the polymerase chain reaction (PCR) with primer pair P1/P7 from Virginia creeper (Parthenocissus quinquefolia) and other plant species infected with elm yellows (16SrV) group phytoplasmas. Fragment profiles were resolved by ethidium bromide staining after electrophoresis through $8 \%$ polyacrylamide gels. Template DNAs for PCR were derived from VC, symptomless Virginia creeper plants; or phytoplasma strains EY1, elm yellows; JWB, jujube witches'-broom; FD70, flavescence dorée; and RuS, Rubus stunt. P1/P7 products were digested with A, AluI, B, $M s p \mathrm{I}$, ,C, $R s a \mathrm{I}, \mathbf{D}, B f a \mathrm{I}$, or E, TaqI. pGEM: DNA molecular size (bp) markers in descending order: $2645,1605,1198,676,517,460,396,350,222,179,126,75,65,51,36$. 

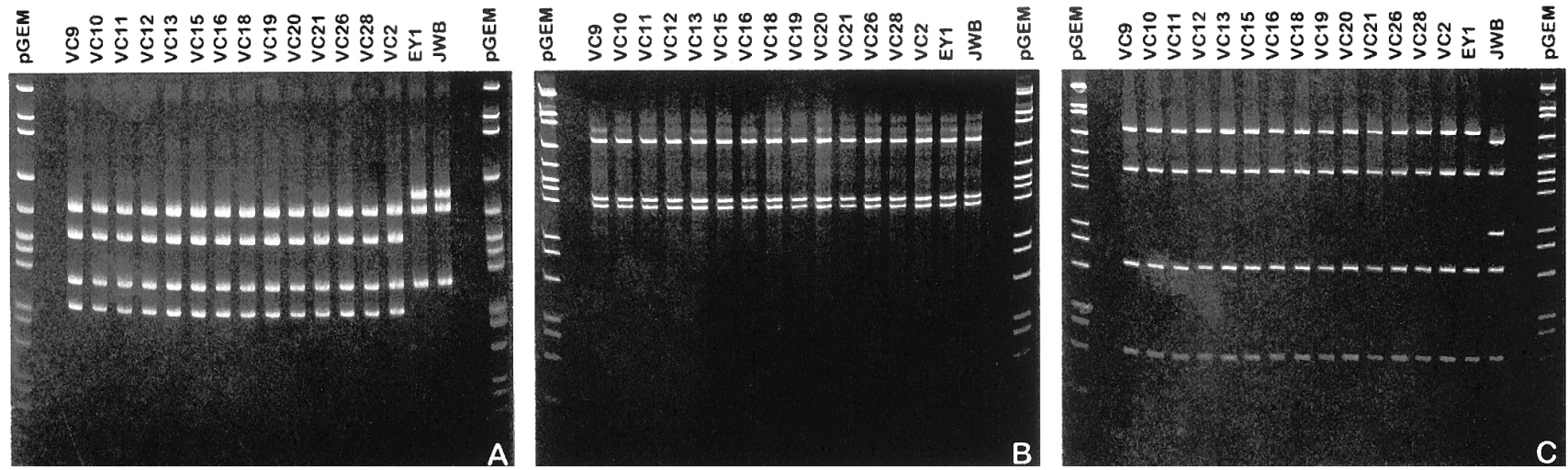

Fig. 4. Comparison of fragment profiles resulting from restriction endonuclease digestion of rDNA products (1.57 kb) reamplified from symptomless Virginia creeper (Parthenocissus quinquefolia) plants by a polymerase chain reaction (PCR) assay incorporating nested elm yellows phytoplasma (16SrV) group-specific rRNA primer pair fB1/rULWS1. Template DNAs for PCR were derived from VC, symptomless Virginia creeper plants; EY1, elm yellows phytoplasma; and JWB, jujube witches'-broom phytoplasma, and digested with A, $B f a \mathrm{I}, \mathbf{B}, R s a \mathrm{I}$, and $\mathbf{C}$, TaqI. pGEM: DNA molecular size (bp) markers in descending order: $2645,1605,1198,676,517,460,396,350,222,179,126,75,65,51,36$.
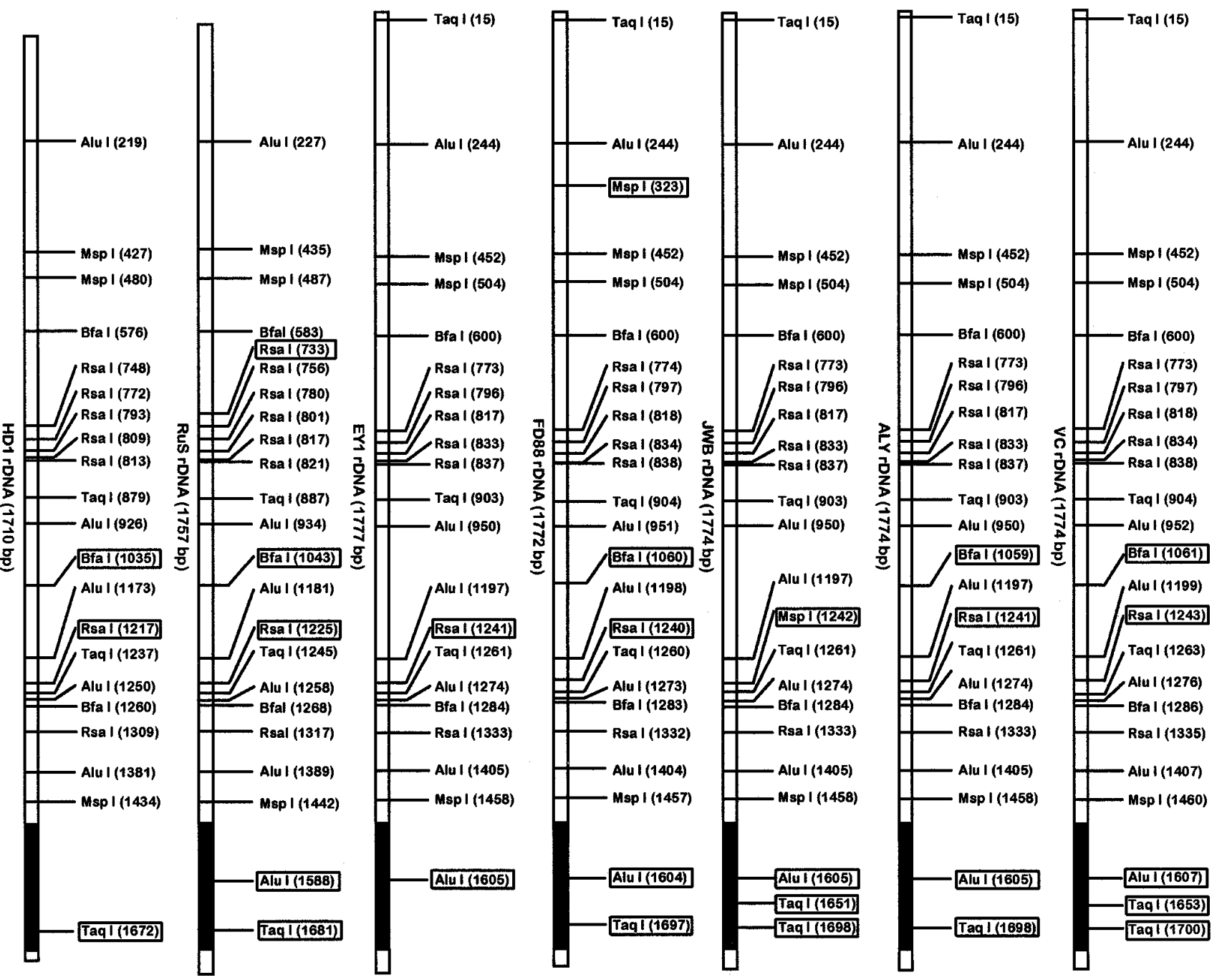

Fig. 5. Analysis of putative restriction sites in rRNA operon sequences of Virginia creeper-associated phytoplasma strain VC2 and related elm yellows $(16 \mathrm{SrV})$ group phytoplasmas. Linear maps were generated using the restriction map option in Vector NTI 5 Suite software (Informax Inc., Bethesda, MD). The region corresponding to the 16-23S rDNA intergenic spacer region sequence is indicated by black color on each map. The identity of each phytoplasma rDNA sequence is as follows: VC, Virginia creeper; ALY, European alder yellows; JWB, jujube witches'-broom; FD88, flavescence dorée; EY1, elm yellows; RuS, Rubus stunt; and HD1, hemp dogbane yellows. Numbers in parentheses in tandem with restriction enzyme labels on maps denote the location of restriction sites within the rDNA sequence. Labels enclosed in boxes delineate restriction site combinations that are uniquely represented in each associated phytoplasma sequence. 
was unique for the $\mathrm{VC}$ phytoplasma whose rDNA sequence $(1,744 \mathrm{bp})$ varied from that of strain ALY (1,744 bp) at only four positions. Of these, substitution of an A for $\mathrm{G}$ at position 1655 in the $16-23 \mathrm{~S}$ intergenic spacer region of strain ALY eliminated a restriction site for TaqI that was present in the VC phytoplasma. The occurrence of an MspI site at $16 \mathrm{~S}$ rDNA position 1242 in conjunction with TaqI sites at positions 1651 and 1698, respectively, within the 16$23 \mathrm{~S}$ spacer, uniquely defined the JWB phytoplasma, a previously designated 16SrV-B subgroup member (20). Phytoplasma strains FD70, EY1, RuS, and HD1 could be similarly differentiated by this means, although the available sequence data for RuS and HD1 was insufficient to establish the existence of a TaqI site located at position 15 on the $16 \mathrm{~S}$ rRNA gene of all five other strains. Putative restriction site analysis also revealed a unique $R s a I$ recognition site located at position 733 in the rDNA sequence of the RuS phytoplasma. By comparison, we noted that the fragment profile generated by actual enzymatic digestion of RuS phytoplasma P1/P7 product with $R s a \mathrm{I}$ also matched the profiles similarly obtained for strains EY1, FD70, and VC (Fig. 3C). As such, we were unable to confirm the occurrence of an extra RsaI site at position 733 in the rDNA sequence of the RuS phytoplasma.

Phylogenetic analysis. A phylogenetic distance tree was constructed from a data set which included 16S rDNA sequences of the VC and JWB phytoplasma strains and comparable sequences of 26 additional strains representing 14 previously established RFLP groups (Fig. 6). The branching orders resolved by this analysis were similar to and supported the same major phylogenetic groups identified in other studies $(3,10)$. In this analysis, both the VC and JWB phytoplasmas clustered closely together along with seven other established EY group members, thereby supporting their assignment to the EY (16SrV) group. Tree branching patterns also indicated that the VC phytoplasma was evolutionarily closest to the European ALY phytoplasma and part of an existing lineage (subgroup $16 \mathrm{SrV}-\mathrm{C}$ ) of strains. By comparison, the JWB phytoplasma gave rise to a new branch not included in previous phylogenetic trees and indicated that this strain represents a separate lineage (subgroup) within the EY group, a prior assertion drawn from results of rDNA RFLP analysis.

\section{DISCUSSION}

The majority of VC plants examined in this study contained phytoplasmas even though none of the infected plants showed any obvious yellows disease symptoms. Similar latent infections have been detected previously in alder (18), velvet ash (36), apricots (16), almonds (40), and wild grapevine (1). These observations support the epidemiological concept of the existence of symptomless host plants which serve as reservoirs for phytoplasma increase and dispersal (35).

Our identification of these strains as members of $16 \mathrm{~S}$ rDNA RFLP group $16 \mathrm{SrV}$ sensu Lee et al. (20) was unexpected because, prior to this finding, the known host range and geographic distribution of $16 \mathrm{SrV}$ phytoplasmas in North America was limited to elm (7), hemp dogbane (8), and possibly grapevine $(1,22)$ in the northeastern United States. Within group $16 \mathrm{SrV}$, both elm- and hemp dogbane-infecting

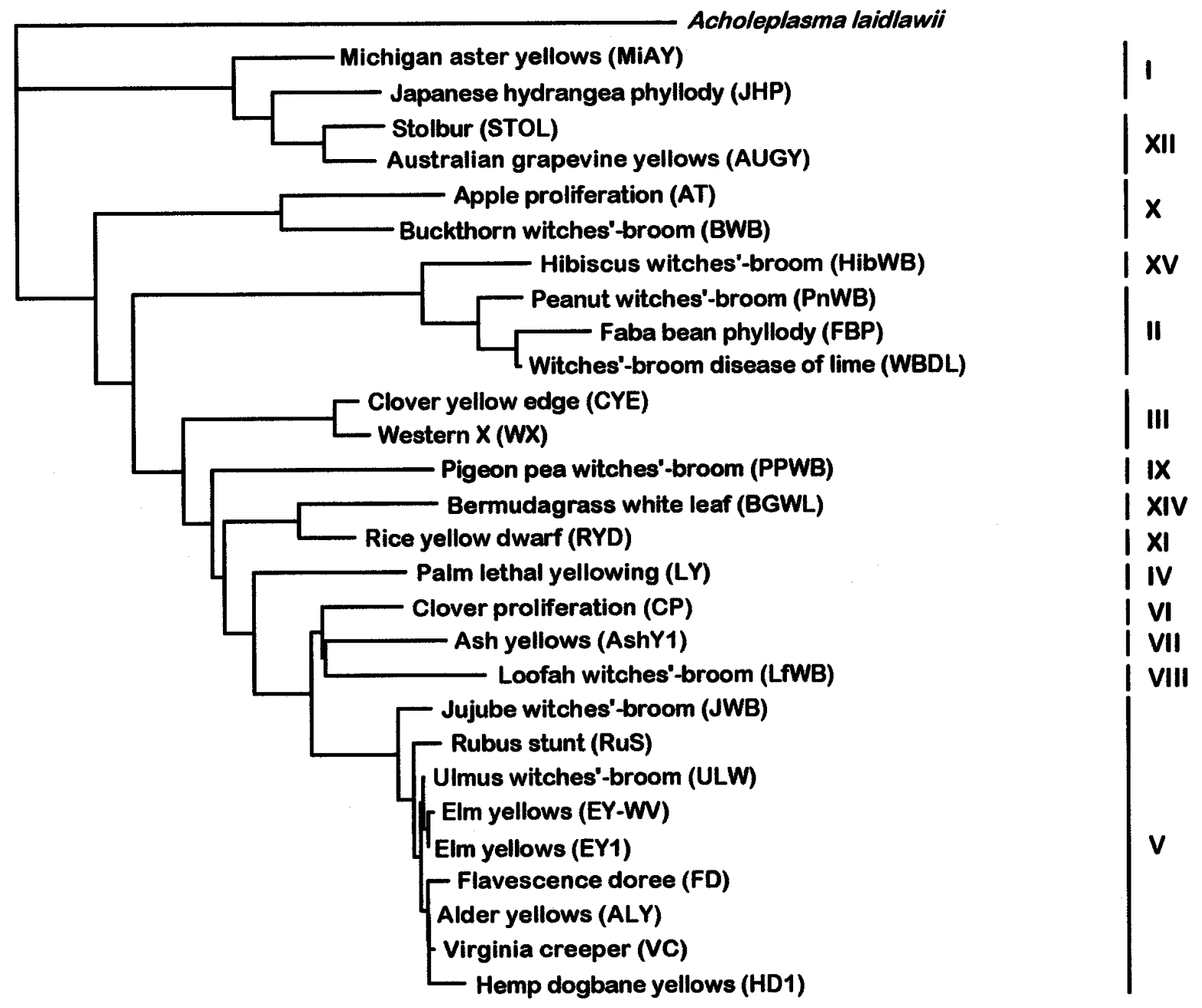

Fig. 6. Phylogenetic tree of $16 \mathrm{~S}$ rRNA gene sequences from 28 phytoplasmas and Acholeplasma laidlawii constructed by the Neighbor-Joining method. $16 \mathrm{~S}$ rRNA restriction fragment length polymorphism group identities are indicated by Roman numerals. 
strains have been further delineated into subgroups $16 \mathrm{SrV}-\mathrm{A}$ and $16 \mathrm{SrV}-\mathrm{C}$, respectively, based on differences in endonuclease recognition sites in their 16S rDNA sequences $(2,20)$. Using this same approach to classification in our work, VCassociated phytoplasmas conformed to previously designated subgroup $16 \mathrm{SrV}-\mathrm{C}$ members.

In contrast to only limited variability of known $16 \mathrm{SrV}$ phytoplasmas in the United States, strains representative of at least four $16 \mathrm{SrV}$ subgroups have been implicated as the etiological agents of diseases affecting a broader range of host plant species in Europe. These include strains associated with Spartium witches'-broom (SpaWB) (34), little leaf of Eucalyptus (24), alder yellows (18), and flavescence dorée of cultivated grapevine, $V$. vinifera (3), all designated members of subgroup 16SrV-C (20). The Rubus stunt phytoplasma (19) previously classified as a $16 \mathrm{SrV}-\mathrm{C}$ strain (20) was recently reassigned to a new subgroup, $16 \mathrm{SrV}$-E, after RFLP patterns generated with endonuclease Tsp509I were shown to distinguish this phytoplasma from others within subgroup $16 \mathrm{SrV}-\mathrm{C}(3)$. By mapping putative recognition sites for Tsp509I in P1/P7-primed rDNA sequences, we found that this endonuclease should be useful for differentiating the VC phytoplasma from other EY group strains, with the exception of ALY, whose sequence yielded a restriction map identical to that of the VC phytoplasma (data not shown).

Griffiths et al. (7) showed that molecular variability among elm-inhabiting and other $16 \mathrm{SrV}$ phytoplasmas could be defined more precisely by considering disparities in key restriction sites for endonucleases AluI $, B f a \mathrm{I}, H p a \mathrm{II}(=M s p \mathrm{I}), R s a \mathrm{I}$, and TaqI in a portion of the rRNA operon that included both the 16S rRNA gene and the noncoding 16-23S rRNA spacer region. By adopting this same approach to characterization of the VC phytoplasma, it was possible to differentiate this agent from other $16 \mathrm{SrV}$ phytoplasmas included for comparative purposes. Moreover, presence or absence of putative restriction sites for AluI and TaqI in the 16-23S spacer region revealed $\mathrm{VC}, \mathrm{HD} 1$, and ALY as three distinct rather than coidentical $16 \mathrm{SrV}-\mathrm{C}$ strains, as could have been deduced from putative RFLP analysis of $16 \mathrm{~S}$ rDNA sequences alone. These findings substantiate and augment results of other studies $(3,7)$ and suggest that subgroup classification based solely on 16S rDNA is probably insufficient to fully account for variability among $16 \mathrm{SrV}$ group phytoplasmas. Further support for this contention was also provided by the outcome of PCR with nonribosomal primer pair FD9f/FD9r, an assay that reportedly detects FD (2) as well as other $16 \mathrm{SrV}$ group phytoplasmas, such as HD1 (8). In our study, this assay consistently failed to amplify any detectable product from phytoplasma-infected VC plants. Thus, sequence variation in the 16$23 \mathrm{~S}$ spacer region between the VC phytoplasma and other $16 \mathrm{SrV}$ phytoplasmas was also accompanied by a demonstrable difference in another as yet uncharacterized region of the genome of the former strain.

Analyses of additional conserved genes, such as ribosomal protein (rp) genes (10), and the gene encoding elongation factor $T u$ (33) have been used to support and refine subgroup classifications based upon 16S rRNA sequences. Presently, these efforts have been focused primarily on phytoplasmas composing groups 16SrI (aster yellows and related strains) (23) and 16SrIII (western $\mathrm{X}$ and related strains) (11) and, to a much lesser extent, on strains composing group $16 \mathrm{SrV}$. By inclusion of rp gene RFLPs in a revision of an earlier classification scheme, Lee et al. (20) demonstrated that further distinction between the $16 \mathrm{SrV}$ B subgroup phytoplasmas cherry lethal yellows (CLY) and JWB was possible. These results suggest that rp gene analysis could help to clarify relationships between other members of this taxonomic group.

In the absence of known symptoms, plant host range, and vector insects, the phytopathological significance of phytoplasma-infected VC remains to be determined. Further examination of this ecologically dominant species for evidence of phytoplasma infection at other sites in southern Florida and in areas where diseases attributed to $16 \mathrm{SrV}$ group phytoplasmas have been previously described seems warranted. The high incidence of infection among plants sampled at the FLREC suggests a close ecological association between this plant species and insects that serve as vectors of the $\mathrm{VC}$ phytoplasma. Knowledge of this relationship should facilitate vector identification attempts. Of the currently recognized plant hosts of $16 \mathrm{SrV}$ phytoplasmas, several Rubus and wild Vitis spp. are indigenous to southern Florida. Whether these plants and eucalyptus, an introduced species, represent possible alternative hosts of the VC phytoplasma is unknown. Only the ubiquitous wild grapevines were found growing in close proximity to VC at the FLREC. Thus far, we have not observed yellows disease symptoms on this candidate host, nor have we detected $16 \mathrm{SrV}$ group phytoplasmas in symptomless grapevines or in Ampelopsis arborea (L.) Koehne (peppervine), another native vitaceous species (N. A. Harrison, unpublished data). Currently, these provisional observations lend support to the hypothesis that diseases attributed to different $16 \mathrm{SrV}$ subgroup phytoplasmas may be mutually exclusive (5).

\section{ADDENDUM}

After this paper was accepted for publication, the following paper was published: Montano, $\mathrm{H}$. G., Davis, R. E., Dally, E. L., Hogenhout, S., Pimentel, J. P., and Brioso, P. S. T. 2001. 'Candidatus Phytoplasma brasiliense', a new phyto- plasma taxon associated with hibiscus witches broom disease. Int. J. Syst. Evol. Microbiol. 51:1109-1118.

\section{ACKNOWLEDGMENTS}

We thank E. Boa, L. Kenyon, B. Kirkpatrick, E. Seemüller, and J. Tsai for providing sources of phytoplasma strains used for comparative purposes in this study.

\section{LITERATURE CITED}

1. Chen, K. H., Guo, J. R., Wu, X. Y., Loi, N., Carraro, L., Guo, Y. H., Chen, Y. D., Osler, R. Pearson, R., and Chen T. A. 1993. Comparison of monoclonal antibodies, DNA probes and PCR for detection of the grapevine yellows disease agent. Phytopathology 83:915922.

2. Daire, X., Clair, D., and Boudon-Padieu, E. 1997. Detection and differentiation of grapevine yellows phytoplasmas belonging to the elm yellows group and to the stolbur group by PCR amplification of non-ribosomal DNA. Eur. J. Plant Pathol. 103:507-514.

3. Davis, R. E., and Dally, E. L. 2001. Revised subgroup classification of group $16 \mathrm{SrV}$ phytoplasmas and placement of flavescence dorée-associated phytoplasmas in two distinct subgroups. Plant Dis. 85:790-797.

4. Davis, R. E., Jomantiene, R., Dally, E. L., and Wolf, T. K. 1998. Phytoplasmas associated with grapevine yellows in Virginia belong to group 16SrI, subgroup A (tomato big bud phytoplasma subgroup) and group 16SrIII, new subgroup I. Vitis 37:131-137.

5. Davis, R. E., and Sinclair, W. A. 1998. Phytoplasma identity and disease etiology. Phytopathology 88:1372-1376.

6. Doyle, J. J., and Doyle, J. L. 1990. Isolation of plant DNA from fresh tissue. Focus 12:1315

7. Griffiths, H. M., Sinclair, W. A., BoudonPadieu, E., Daire, X., Sfalaga, A., and Bertaccini, A. 1999. Phytoplasmas associated with elm yellows: Molecular variability and differentiation from related organisms. Plant Dis. 83:1101-1104.

8. Griffiths, H. M., Sinclair, W. A., Davis, R. E., Lee, I.-M., Dally, E. L., Guo, Y.-H., Chen, T. A., and Hibben, C. R. 1994. Characterization of mycoplasmalike organisms from Fraxinus, Syringa and associated plants from geographically diverse sites. Phytopathology 84:119-126.

9. Griffiths, H. M., Sinclair, W. A., Smart, C. D., and Davis, R. E. 1999. The phytoplasma associated with ash yellows and lilac witches'broom: "Candidatus Phytoplasma fraxini". Int. J. Syst. Bacteriol. 49:1605-1614.

10. Gundersen, D. E., Lee, I.-M., Rehner, S. A., Davis, R. E., and Kingsbury, D. T. 1994. Phylogeny of mycoplasmalike organisms (phytoplasmas): a basis for their classification. J. Bacteriol. 176:5244-5254.

11. Gundersen, D. E., Lee, I.-M., Schaff, D. A. Harrison, N. A., Chang, C. J., Davis, R. E., and Kingsbury, D. T. 1996. Genomic diversity and differentiation among phytoplasma strains in 16S rRNA group I (aster yellows and related phytoplasmas) and III (X-disease and related phytoplasmas). Int. J. Syst. Bacteriol. 46:64-75.

12. Harrison, N. A., Richardson, P. A., Kramer, J. B., and Tsai, J. H. 1994. Detection of the phytoplasma associated with lethal yellowing disease of palms in Florida by polymerase chain reaction. Plant Pathol. 43:998-1008.

13. Harrison, N. A., Richardson, P. A., Tsai, J. H., Ebbert, M. A., and Kramer, J. B. 1996. PCR assay for detection of the phytoplasma associated with maize bushy stunt disease. Plant Dis. 80:263-269

14. Harrison, N. A., Tsai, J. H., Bourne, C. M., 
and Richardson, P. A. 1991. Molecular cloning and detection of chromosomal and extrachromosomal DNA of mycoplasmalike organisms associated with witches'-broom disease of pigeon pea in Florida. Mol. PlantMicrobe Interact. 4:300-307.

15. Innis, M. A., and Gelfand, D. H. 1990. Optimization of PCRs. Pages 3-12 in: PCR Protocols: A Guide to Methods and Applications. M. A. Innis, D. H. Gelfand, J. J. Sninsky, and T. J. White, eds. Academic Press, Inc., San Diego, CA

16. Kirkpatrick, B. C., Fisher, G. A., Fraser, J. D., and Purcell, A. H. 1990. Epidemiological and phylogenetic studies on western X-disease mycoplasmalike organisms. Pages 288-297 in: Recent Advances in Mycoplasmology. G. Stanek, G. H. Cassell, J. G. Tully, and R. F. Whitcomb, eds. Gustav Fischer Verlag, New York.

17. Kirkpatrick, B. C., Harrison, N. A., Lee, I.-M., Neimark, H., and Sears, B. B. 1995. Isolation of mycoplasma-like organism DNA from plant and insect hosts. Pages 105-117 in: Molecular and Diagnostic Procedures in Mycoplasmology. Vol 2. S. Razin and J. G. Tully, eds. Academic Press, New York.

18. Lederer, W., and Seemüller, E. 1991. Occurrence of mycoplasma-like organisms in diseased and non-symptomatic alder trees (Alnus spp.). Eur. J. For. Pathol. 21:90-96.

19. Lee, I.-M., Davis, R. E., Sinclair, W. A., DeWitt, N. D., and Conti, M. 1994. Genetic relatedness of mycoplasmalike organisms in Ulmus spp. in the United States and Italy by means of DNA probes and polymerase chain reactions. Phytopathology 83:829-833.

20. Lee, I.-M., Gundersen-Rindal, D. E., Davis, R. E., and Bartoszyk, I. M. 1998. Revised classification scheme of phytoplasmas based on RFLP analyses of $16 \mathrm{~S}$ rRNA and ribosomal protein gene sequences. Int. J. Syst. Bacteriol. 48:1153-1169.

21. Lim, P.-O., and Sears, B. B. 1989. 16S rRNA sequence indicates that plant-pathogenic mycoplasma-like organisms are evolutionarily distinct from animal mycoplasmas. J. Bacteriol. 171:5901-5906.

22. Maixner, M., Pearson, R. C., Boudon-Padieu, E., and Caudwell, A. 1993. Scaphoideus titanus, a possible vector of grapevine yellows in New York. Plant Dis. 77:408-413.
23. Marcone, C., Lee, I.-M., Davis, R. E., Ragozzino, A., and Seemüller, E. 2000. Classification of the aster yellows-group phytoplasmas based on combined analyses of rRNA and tuf gene sequences. Int. J. Syst. Evol. Microbiol. 50:1703-1713.

24. Marcone, C., Ragozzino, A., and Seemüller, E. 1996. Detection of an elm yellows phytoplasma in Eucalyptus trees affected by littleleaf disease in Italy. Plant Dis. 80:669-673.

25. Martini, M., Murari, E., Mori, N., and Bertaccini, A. 1999. Identification and epidemic distribution of two flavescence dorée-related phytoplasmas in Veneto (Italy). Plant Dis. 83:925-930.

26. Mäurer, R., Seemüller, E., and Sinclair, W. A. 1993. Genetic relatedness of mycoplasmalike organisms affecting elm, alder and ash in Europe and North America. Phytopathology 83:971-976.

27. Namba, S., Oyiazu, H., Kato, S., Iwanami, S., and Tsuchizaki, T. 1993. Phylogenetic diversity of phytopathogenic mycoplasmalike organisms. Int. J. Syst. Bacteriol. 43:461-467.

28. Nixon, E. S., Ward, J. R., Fountain, E. A., and Neck, J. S. 1991. Woody vegetation of an oldgrowth creekbottom forest in north-central Texas. Texas J. Sci. 43:157-164.

29. Padovan, A. Gibb, K., Daire, X., and BoudonPadieu, E. 1996. A comparison of phytoplasma associated with Australian grapevine yellows to other phytoplasmas in grapevine. Vitis 35:189-194.

30. Page, R. D. 1996. TreeView: an application to display phylogenetic trees on personal computers. Comput. Appl. Biosci. 12:357-358.

31. Prince, J. P., Davis, R. E., Wolf, T. K., Lee, I.M., Mogen, B. D., Dally, E. L., Bertaccini, A., Credi, R., and Barba, M. 1993. Molecular detection of diverse mycoplasmalike organisms (MLO) associated with grapevine yellows and their classification with aster yellows, X-disease and elm yellows MLOs. Phytopathology 83:1130-1137.

32. Sawayanagi, T., Horikoshi, N., Kanehira, T., Shinohara, M., Bertaccini, A., Cousin, M.-T., Hiruki, C., and Namba, S. 1999. "Candidatus Phytoplasma japonicum", a new phytoplasma taxon associated with Japanese hydrangea phyllody. Int. J. Syst. Bacteriol. 49:12751285 .
33. Schneider, B., Gibb, K. S. and Seemüller, E. 1997. Sequence and RFLP analysis of the elongation factor Tu gene used in differentiation and classification of phytoplasmas. Microbiology 143:3381-3389.

34. Seemüller, E., Marcone, C., Lauer, U. Ragozzino, A., and Goeschl, M. 1998. Current status of molecular classification of the phytoplasmas. J. Plant Pathol. 80:3-26.

35. Sinclair, W. A., Griffiths, H. M., and Lee, I.M. 1994. Mycoplasmalike organisms as causes of slow growth and decline of trees and shrubs. J. Arboric. 20:176-189.

36. Sinclair, W. A., Griffiths, H. M., and Treshow, M. 1994. Ash yellows in velvet ash in Zion National Park: high incidence but low impact. Plant Dis. 84:486-490.

37. Sinclair, W. A., Iuli, R. J., Dyer, A. T., and Larsen, A. O. 1989. Sampling and histological procedures for diagnosis of ash yellows. Plant Dis. 73:432-435.

38. Smart, C. D., Schneider, B., Blomquist, C. L. Guerra, L. J., Harrison, N. A., Ahrens, U., Lorenz, K.-H., Seemüller, E., and Kirkpatrick, B. C. 1996. Phytoplasma-specific PCR primers based on sequences of the 16-23S rRNA spacer region. Appl. Environ. Microbiol 62:2988-2993

39. Tymon, A. M., Jones, P., and Harrison, N. A 1998. Phylogenetic relationships of coconu phytoplasmas and the development of specific oligonucleotide PCR primers. Ann. Appl. Biol. 132:437-452.

40. Uyemoto, J. K., Connell, J. H., Hasey, J. K. and Luhn, C. F. 1992. Almond brown line and decline: a new disease probably caused by a mycoplasma-like organism. Ann. Appl. Biol. 120:417-424.

41. Weisburg, W. G., Tully, J. G., Rose, D. L. Petzel, J. P., Oyaizu, H., Mandelco, L., Sechrest, J., Lawrence, T. G., Van Etten, J., Maniloff, J., and Woese, C. R. 1989. A phylogenetic analysis of the mycoplasmas: basis for their classification. J. Bacteriol. 171:6455 6467.

42. Zreik, L., Carle, P., Bové, J. M., and Garnier, M. 1995. Characterization of the mycoplasmalike organism associated with witches' broom disease of lime and proposition of a Candidatus taxon for the organism, "Candidatus Phytoplasma aurantifolia”. Int. J. Syst. Bacteriol. 45:449-453. 